\title{
The Sutherland-Glueck Debate: On the Sociology of Criminological Knowledge
}

\section{Citation}

Laub, John H., and Robert J. Sampson. 1991. The Sutherland-Glueck debate: On the sociology of criminological knowledge. American Journal of Sociology 96, no. 6: 1402-1440. Reprinted in Piers Beirne, ed., Origins and Growth of Criminology (Dartmouth Publishing, 1994).

\section{Published Version}

http://dx.doi.org/10.1086/229691

\section{Permanent link}

http://nrs.harvard.edu/urn-3:HUL.InstRepos:3226954

\section{Terms of Use}

This article was downloaded from Harvard University's DASH repository, and is made available under the terms and conditions applicable to Other Posted Material, as set forth at http:// nrs.harvard.edu/urn-3:HUL.InstRepos:dash.current.terms-of-use\#LAA

\section{Share Your Story}

The Harvard community has made this article openly available.

Please share how this access benefits you. Submit a story.

\section{Accessibility}




\title{
CHICAgo JOURnals
}

\author{
The Sutherland-Glueck Debate: On the Sociology of Criminological Knowledge \\ Author(s): John H. Laub and Robert J. Sampson \\ Source: The American Journal of Sociology, Vol. 96, No. 6 (May, 1991), pp. 1402-1440 \\ Published by: The University of Chicago Press \\ Stable URL: http://www.jstor.org/stable/2781905
}

Accessed: 02/08/2009 23:12

Your use of the JSTOR archive indicates your acceptance of JSTOR's Terms and Conditions of Use, available at http://www.jstor.org/page/info/about/policies/terms.jsp. JSTOR's Terms and Conditions of Use provides, in part, that unless you have obtained prior permission, you may not download an entire issue of a journal or multiple copies of articles, and you may use content in the JSTOR archive only for your personal, non-commercial use.

Please contact the publisher regarding any further use of this work. Publisher contact information may be obtained at http://www.jstor.org/action/showPublisher?publisherCode=ucpress.

Each copy of any part of a JSTOR transmission must contain the same copyright notice that appears on the screen or printed page of such transmission.

JSTOR is a not-for-profit organization founded in 1995 to build trusted digital archives for scholarship. We work with the scholarly community to preserve their work and the materials they rely upon, and to build a common research platform that promotes the discovery and use of these resources. For more information about JSTOR, please contact support@jstor.org. 


\title{
The Sutherland-Glueck Debate: On the Sociology of Criminological Knowledge ${ }^{1}$
}

\author{
John H. Laub \\ Northeastern University \\ Robert J. Sampson \\ University of Illinois at Urbana-Champaign
}

\begin{abstract}
During the 1930s, Edwin Sutherland established the sociological model of crime as the dominant paradigm in criminology and as a result became the most influential criminologist of the 20th century. This article examines Sutherland's debate with Sheldon Glueck and Eleanor Glueck about the causes of crime and the proper focus of social science research. Previously unavailable correspondence and unpublished papers are examined along with published works from the period (1925-45) when Sutherland was developing the theory of differential association and the Gluecks were launching research on criminal careers. The competing paradigms of the Gluecks and Sutherland are also placed in the socio-intellectual and institutional context in which they worked. It is shown that Sutherland's attack on the Gluecks' interdisciplinary research program was driven by: (a) a substantive version of sociological positivism that attempted to establish criminology as the proper domain of sociology, $(b)$ a commitment to the method of analytic induction, and $(c)$ Sutherland's rise to prominence in sociology. In addition, key aspects of the Gluecks' perspective reflecting their own professional interests in law and psychiatry further contributed to sociologists' hostile reaction. Nevertheless, the article presents evidence that the Gluecks' research on such fundamental issues as age and crime, criminal careers, and social control is more correct than commonly believed and, in fact, occupies center stage in contemporary research.
\end{abstract}

Edwin Sutherland (1883-1950) has been widely acclaimed as the dominant criminologist of the 20th century. Indeed, Principles of Criminology

\footnotetext{
${ }^{1}$ We are grateful to the members of the Manuscript Division of the Harvard Law School Library for their assistance in the production of this paper. We would also like to thank David Bordua, Jan Gorecki, Michael Gottfredson, Robert Alun Jones, Kenna Davis, Janet Lauritsen, and three anonymous $A J S$ reviewers for their helpful com-

(c) 1991 by The University of Chicago. All rights reserved. 0002-9602/91/9606-0003\$01.50
} 
([1924] 1978), ${ }^{2}$ The Professional Thief (1937a), and White Collar Crime $(1949,1983)$ are classic works still read by students of criminology. It is true as well that most criminologists are familiar with the works of Sutherland's students (e.g., Donald Cressey, Albert Cohen, and Lloyd Ohlin). Moreover, assessments of Sutherland's contributions to criminology are widely available (see, e.g., Cohen, Lindesmith, and Schuessler 1956; Schuessler 1973; and Gaylord and Galliher 1988). The Sutherland legacy in the sociology of crime is thus well established and secure. In fact, as recently as 1979 Gibbons argued that the "evidence is inconvertible that Edwin Sutherland was the most important contributor to American criminology to have appeared to date." He goes as far as to predict that "it is extremely unlikely that anyone will emerge in future decades to challenge Sutherland's position in the annals of the field" (1979, p. 65). Similarly, Mannheim (1965, p. 470) has suggested that Sutherland receive the equivalent of a Nobel Prize in criminology.

In sharp contrast to the Sutherland legacy stands the work of Sheldon Glueck (1896-1980) and Eleanor Glueck (1898-1972). For over 40 years the Gluecks performed fundamental research in the field of criminology. As shown below, not only did their research provide crucial knowledge on the causes of crime, the Gluecks' research agenda set the stage for battles currently being waged in criminology regarding the proper focus of the discipline and the role of the scientific method. But despite their seminal contributions to the field, the Gluecks' works have been either ignored or criticized-especially by sociologists. As a result, contemporary researchers rarely, if ever, read their original studies. And when perfunctory citations do appear, their purpose is usually to allege fatal flaws in the Gluecks' position. Current debates in criminology have thus emerged as if there were no precedent.

Why have such developments taken place? It is our contention that the accepted fates of Sutherland and the Gluecks are intimately connected and cannot be understood by simple reference to the truth or falsity of their research findings. Instead, the Gluecks' research must be placed in the intellectual and historical context of Sutherland's rise to the position of the dominant sociologist of crime in the 20th century. We argue that

ments on an earlier draft. Requests for reprints should be sent to John H. Laub, College of Criminal Justice, 360 Huntington Avenue., Northeastern University, Boston, Massachusetts 02115 .

${ }^{2}$ The first edition, published in 1924, was entitled Criminology. In 1934 the second, revised edition appeared under the title Principles of Criminology. Sutherland alone authored a total of four different editions; the fifth edition (1955) was written with the late Donald Cressey, who remained a coauthor through the tenth edition (1978). All 10 editions of the text have been published by J.B. Lippincott. 
a shift in Sutherland's disciplinary and methodological outlook resulted in a theory that virtually required him to destroy individual-level, or nonsociological, perspectives on crime. The Gluecks advocated a multiple-factor theory of crime, which to Sutherland represented a threat to the intellectual status of sociological criminology. Hence, Sutherland's attack was aimed largely at extinguishing their interdisciplinary model so that sociology could establish proprietary rights to criminology. Although Sutherland's coup was successful at the time and remains so in some circles today, we demonstrate that in important respects it was unfounded and driven by a distorted version of both sociological positivism and the Gluecks' research. At the same time we show how the Gluecks' professional interests contributed to their own demise.

To substantiate our claims we examine in detail a previously unanalyzed debate between Edwin Sutherland and the Gluecks about the causes of crime and proper methods of social science research. After a period of initial harmony in the late 1920s and early 1930s, the Sutherland-Glueck exchange became heated and took on the trappings of an intellectual shoot-out that lasted some 15 years. This is the period when Sutherland was developing his famous theory of differential association and the Gluecks were studying the development of criminal careers and the effectiveness of correctional treatment in reducing criminal behavior. The material we analyze includes both published works and previously unavailable correspondence as well as unpublished papers. We uncovered the correspondence and unpublished manuscripts, along with the original raw data for the Gluecks' studies, in the archives of the Harvard Law School Library. The correspondence, unpublished papers, and raw data provide a unique glimpse into the formation and development of some of the major criminological works of our time. As Schuessler has argued, "Sutherland's contribution to criminology consisted as much in his informal papers and letters as in his published writing" (1973, p. xxiii). We believe the same is true of the Gluecks.

We also place the competing research paradigms of the Gluecks and Sutherland in the socio-intellectual and institutional context in which they found themselves. We argue that the formation and substance of their theoretical positions were deeply affected by their respective methodological and disciplinary biases. To understand the latter, we found it necessary to uncover the contextual factors relating to the intellectual climate and social positions to which each party was witness (see esp. Jones 1977, 1986; Camic 1987; Beirne 1987; Laub 1983).

Finally, we reassess the Gluecks' research findings in light of recent criminological advances and the test of time. In so doing we identify four substantive and methodological characteristics of the Glueck perspective that have captured center stage in current research. These include such 
salient issues as age and crime, the value of longitudinal research, criminal careers, and social control theory. We show that, although largely unacknowledged today, the Gluecks' substantive contributions are fundamental to theory and research in the study of crime.

\section{HISTORICAL AND INSTITUTIONAL CONTEXT}

The historical context and institutional affiliations of the Gluecks had an important effect on their methodological stance and later dealings with Sutherland in three respects. First, unlike Sutherland's, the Gluecks' educational background was eclectic and interdisciplinary in nature. Sheldon Glueck in particular was something of an academic maverick. He first attended Georgetown University (1914-15) and then transferred to George Washington University where he received his A.B. degree in the humanities in 1920. He went on to receive an LL.B. and LL.M. from National University Law School in 1920. After being denied admission to Harvard Law School, Glueck subsequently entered the Department of Social Ethics at Harvard University, which was an interdisciplinary precursor to the sociology department (see Potts [1965] for a fascinating description of that department). There he received an A.M. in 1922 and Ph.D. in $1924 .^{3}$ Eleanor Glueck's academic terrain was similarly eclectic-after attending Barnard College (A.B. in English, 1920) and working in a settlement house in Dorchester, Massachusetts, she enrolled in the School of Education at Harvard and took an Ed.M. degree in 1923 and a doctorate (Ed.D.) in 1925. ${ }^{4}$ (Both Sheldon and Eleanor Glueck were also given honorary doctorates by Harvard University in 1958.) As a team the Gluecks were thus not beholden to any one discipline in an "a priori" sense, and, as a result, they published extensively in the leading journals of criminology, social work, psychology, sociology, education, law, and psychiatry. ${ }^{5}$ As will become more apparent below, the price they paid for such an interdisciplinary outlook was steep. Indeed, as Geis recognized over 20 years ago, "the Gluecks belong to no single academic discipline, and they are suffering the déclasse fate of aliens and intruders" (1966, p. 188).

Second, the Gluecks' social positions within the academic community

\footnotetext{
${ }^{3}$ Sheldon Glueck's (1925) Ph.D. thesis crosscut the interests of sociology, law, and psychiatry, focusing on criminal responsibility, mental disorder, and criminal law.

${ }^{4}$ Eleanor Glueck's early research focused on the sociology of education (community and schools) and the evaluation of research methods in social work (1927, 1936; see also Gilboy 1936 and Vaillant 1980).

${ }^{5}$ A bibliography of the Gluecks' works from 1923 to 1963 is published in Glueck and Glueck (1964).
} 
were unique at the time and would be even today. After teaching a few years in the Department of Social Ethics at Harvard, Sheldon Glueck was appointed to the Harvard Law School as assistant professor of criminology in 1929. He became a full professor in 1931 and was appointed the first Roscoe Pound Professor of Law in 1950 (Current Biography Yearbook 1957). Sheldon Glueck's position as a professor of criminology in a law school was an unusual institutional arrangement that led him to a somewhat isolated and "outcast" perspective. Specifically, although law professors and students do not often conduct (or reward) social science research, that was his specialty and main interest. Moreover, research on the causes of crime was a particular anomaly in the law school setting, though it should be noted that during the 1930s the Harvard Law School had a tradition of research on the administration of justice (e.g., the Cleveland Crime Survey and the Harvard Crime Survey). Sheldon Glueck's institutional arrangement was a structural constraint in yet another crucial respect-there was no opportunity to train Ph.D. students who might carry on the Gluecks' research agenda. ${ }^{6}$

Perhaps more salient was the institutional treatment accorded Eleanor Glueck. Although armed with a doctorate in education and a prolific publishing record, ${ }^{7}$ Eleanor Glueck was unable to secure a tenured faculty position or any teaching position at Harvard. In fact, she was employed from 1930 to 1953 as a research assistant in criminology at the Harvard Law School. ${ }^{8}$ Some 20 years after her appointment as a research assistant she was "promoted" to research associate in criminology in 1953, a position she retained until 1964. At the same time, from 1929 to 1964, she was codirector of the project on the causes and prevention of juvenile delinquency. ${ }^{9}$ In short, Eleanor Glueck's entire career at Harvard University consisted of a social position akin to what many Ph.D. candidates face today before graduation. As such, she was an outcast from mainstream academia at Harvard.

The third fact central to understanding the Gluecks' approach was

\footnotetext{
${ }^{6}$ The contrast to the structural arrangement of Edwin Sutherland with regard to graduate students is important and is addressed further below.

${ }^{7}$ Eleanor Glueck received her doctorate in educational sociology at the Harvard Graduate School of Education, the only school at Harvard at that time that admitted women.

${ }^{8}$ Harvard Law School did not admit women as students until 1950; it was the last Ivy League school to do so. Even then, it has been noted that during the 1950s and 1960s women at Harvard Law School were "treated like members of an alien species" (Abramson and Franklin 1986, p. 10).

${ }^{9}$ Although the Gluecks' research was carried out under the auspices of the Harvard Law School, their research was funded by numerous private foundations. Eleanor Glueck spent an enormous amount of time on this fund-raising activity.
} 
that their intellectual mentors were a diverse group drawn from a variety of disciplines and all unusual thinkers in their own right. The group included such figures as Roscoe Pound, Felix Frankfurter, Richard Cabot, Bernard Glueck, William Healy, Augusta Bronner, and Edwin B. Wilson. This diversity of intellectual influence is evident throughout the Gluecks' research careers. Early on, the Gluecks were influenced personally as well as professionally by Sheldon Glueck's older brother, Bernard Glueck. The latter was a forensic psychiatrist at Sing Sing Prison and had a long-standing interest in crime (see B. Glueck 1916, 1918). Perhaps equally important, it was Bernard Glueck who arranged the first meeting between one of his graduate students, Eleanor Touroff, and Sheldon Glueck.

At Harvard the Gluecks were influenced by Richard C. Cabot, a professor in the Department of Social Ethics. It was in a seminar with Professor Cabot that the idea for a study of 500 offenders from the Massachusetts Reformatory first originated. Cabot's own research utilized the follow-up method in assessing the accuracy of diagnoses of cardiac illnesses (see Cabot 1926). Sheldon Glueck noted that in the field of penology no studies had been done assessing the posttreatment histories of former prisoners. Excited by the prospects of such research, Cabot arranged financing for the Gluecks' research, which culminated in 500 Criminal Careers (1930).

Felix Frankfurter served as director of the Harvard Crime Survey in 1926 and was also quite influential in the Gluecks' early studies. In fact, the Harvard Crime Survey, of which One Thousand Juvenile Delinquents (1934a) is volume 1 in a series of reports, can be seen as an early model of scientific inquiry in the social sciences. According to Frankfurter, the survey was "not an agency for reform" but a contribution of scientific knowledge to society in the areas of criminal behavior and social policy that "heretofore had been left largely to improvisation, crude empiricism, and propaganda" (1934, p. xii). Moreover, Frankfurter (1934) believed that the formulation of the problem and use of the scientific process to address the problem would eventually lead to prudent social policies. This general perspective can be found in all the Gluecks' research.

William Healy and Augusta Bronner probably wielded the most influence in the Gluecks' intellectual history. The Gluecks had met Healy and Bronner, who were the directors of the Judge Baker Foundation, when they first arrived in Boston, a meeting facilitated in part by Bernard Glueck. The Gluecks had read Healy's The Individual Delinquent (1915) and were favorably disposed to his research. At the same time, Healy was interested in issues relating to Sheldon Glueck's doctoral thesis and was one of the reviewers who encouraged its publication by Little, Brown 
(S. Glueck 1964, p. 319). Most important to the Gluecks was the "scientific attitude" of Healy and Bronner and, in a memorial address for Healy, Sheldon Glueck stated that he was "a major catalyst of our work" (1964, p. 319). Like the Gluecks, Healy focused on the individual as the most important unit of analysis, embraced a multiple-factor approach in the study of crime causation, and utilized knowledge across a variety of disciplines (see Healy 1915; and Healy and Bronner 1926). In fact, Snodgrass (1972, p. 326) has referred to Unraveling Juvenile Delinquency (Glueck and Glueck 1950a) as "essentially a modernized Individual Delinquent."

In short, three factors worked together to develop a fiercely independent, interdisciplinary, and even iconoclastic outlook on the part of the Gluecks. In particular, interdisciplinary educational training, coupled with Sheldon Glueck's unusual position in the law school and apparent gender discrimination against Eleanor Glueck, served to create almost a bunker mentality on the part of the Gluecks, especially regarding Harvard sociology. ${ }^{10}$ The Gluecks were also constrained by their lack of involvement in the training of graduate students. Added to this was the intellectual diversity of a set of colleagues who fostered empirical research beyond the confines of any one discipline. It is only within this context that we can now understand the Gluecks' theoretical and methodological perspective.

\section{The Glueck Perspective}

During their 40-year career at the Harvard Law School, the Gluecks produced four major data bases relating to crime and delinquency. The first was the study of 510 male offenders from the Massachusetts Reformatory during the period 1911-22. These offenders were studied over a 15-year span, which resulted in three books (Glueck and Glueck 1930, $1937 a$, 1943). A second although similar study of women incarcerated at the Women's Reformatory resulted in the publication of Five Hundred Delinquent Women (1934b). A third major research effort focused on a sample of juveniles who had been referred by the Boston juvenile court

\footnotetext{
${ }^{10}$ Harvard sociology in the 1930s has been described as "intellectually ill-defined" (Camic 1987, p. 425). The powers that did exist (e.g., Sorokin, Parsons, and Homans) certainly did not consider the study of crime to be central to the mission of sociology (see Faculty Committee Report 1954, and Cohen's interview in Laub [1983]). In fact, the parallel between Parsons's pursuit of general sociological theory at Harvard (see Camic 1987) and Sutherland's at Indiana, is striking. It should also be noted that both Sheldon and Eleanor Glueck were Jewish. One can speculate that discrimination against Jews at Harvard University (see Laub 1983, p. 185) may have also contributed to isolating the Gluecks from the mainstream academic community.
} 
to the Judge Baker Foundation (the existing court clinic at the time). These results were published in One Thousand Juvenile Delinquents $(1943 a)$, and a follow-up analysis 10 years later produced Juvenile Delinquents Grown Up (1940). The results of these studies are summarized in a volume entitled After-Conduct of Discharged Offenders (1945). Finally, the work the Gluecks are best known for is Unraveling Juvenile Delinquency (1950a). This major study of the formation and development of criminal careers was initiated in the 1940s and involved a sample of 500 delinquents and 500 nondelinquents matched case-by-case on age, race/ ethnicity, general intelligence, and low-income residence-all classic criminological variables thought to influence both delinquency and official reaction. Over a 17-year period the Gluecks conducted an extensive follow-up of the original Unraveling sample, which resulted in the publication of Delinquents and Nondelinquents in Perspective (1968; see also Glueck and Glueck 1970).

The Gluecks' methodological approach to the study of crime can be characterized by three distinct features. The first is an emphasis on longitudinal and follow-up prediction studies, including, when possible, control groups for comparative purposes. Second, the Gluecks' work emphasized a criminal career focus, especially the study of serious persistent offenders (1950a, p. 13). Related to this was the Gluecks' thought that the study of the formation, development, and termination of criminal careers was an important research priority, and that the causes of the initiation of crime were distinct from the causes of continuing crime and processes of desistance (Glueck and Glueck 1930, p. 257; 1934b, p. 282; 1945 , p. 75, n. 1). Third, the Gluecks stressed the importance of collecting multiple sources of information (e.g., parent, teacher, self-report) in addition to official records of delinquency.

As for substantive findings, the Gluecks, like Goring ([1913] 1972), uncovered the important relationship between age and criminality. They argued that age of onset was a key factor in terms of etiology and policy and that career criminals started very young in life. The Gluecks also stressed that crime declined substantially with age. Specifically, in all of their research the Gluecks found that, as the population of offenders aged, their crime rate declined. Furthermore, even among those who continued offending, the seriousness of the offenses declined (Glueck and Glueck 1940, 1943, 1945, 1968). The Gluecks sought to understand the age-crime curve in terms of maturational reform. As we will see, not only was the relationship between age and crime one of the major sources of their battle with Sutherland, it foreshadowed a contemporary debate along similar lines.

Research by the Gluecks also revealed the stability of delinquent patterns over the life cycle. They argued that the data showed "beyond a 
reasonable doubt that, in all of life's activities considered in this inquiry, the men who as boys comprised our sample of juvenile delinquents have continued on a path markedly divergent from those who as juveniles had been included in the control group of nondelinquents" (Glueck and Glueck 1968, pp. 169-70). The Gluecks' hypothesis regarding the stability of deviance would also turn out to be a major sticking point with those advocating a sociological perspective.

According to the Gluecks, the most important factor that distinguished delinquents from nondelinquents in early life was the family. In particular, the Gluecks (1950a) developed a prediction scale of delinquency that centered on family variables-disciplinary practices, supervision by parents, and child-parent attachment. Those families with lax discipline combined with erratic and threatening punishment, poor supervision, and weak emotional ties between parent and child were found to generate the highest probability of delinquency. Although a focus on the family was to become extremely unpopular in sociology during the 1950s and 1960 s, it was one of the Gluecks' major interests.

Perhaps most important, the Gluecks promoted a multidisciplinary perspective and had little patience for those criminologists who were wedded to any one particular discipline. As a result the Gluecks rejected unilateral causation whether sociological, biological, or psychological in focus and embraced instead a multiple causal approach that emphasized differentiation between offenders and nonoffenders. This approach is seen most clearly in Unraveling, in which they focused not only on the family, but on school, opportunities (peers and use of leisure time), formal sanctions (e.g., arrest, probation, prison), personality development, temperament, and constitutional factors such as body structure (e.g., mesomorphy). As they stated, "The separate findings, independently gathered, integrate into a dynamic pattern which is neither exclusively biologic nor exclusively socio-cultural, but which derives from an interplay of somatic, temperamental, intellectual, and socio-cultural forces" (1950a, p. 281). The Gluecks, along with Healy (1915; see also Healy and Bronner 1926), thus established the multiple-factor approach to the study of crime.

Overall, the Gluecks were stubbornly driven by what their data revealed and refused to pigeonhole their interpretations into any one disciplinary box, tempted though they were. This emphasis on fact gathering prevented them from ever developing a systematic theoretical framework. As they argued, "Neither 'hunches' nor theoretical speculations, can conjure away the facts, even though those facts may not fit neatly into various preconceptions about human nature and crime causation" (1951, p. 762). Their mode of analysis was thus to cross-tabulate all possible factors with delinquency (cf. Lazarsfeld 1955). As a result, $U n$ - 
raveling is very difficult to read and seems to present nothing but table after table. As Geis has noted, "The paradox of studies by the Gluecks: they do such good work so badly" (1970, p. 118; see also Laub and Sampson [1988] for a review of the methodological criticisms of Unraveling).

We will return later to the validity of the Gluecks' major research findings regarding such issues as age and crime, family processes, and the stability of crime and deviance across the life course. For now, we hope to have established the basic Glueck perspective and placed it in the historical and institutional context specified above. In similar fashion we turn our attention next to the Gluecks' major contemporary and critic.

\section{The Initial Sutherland Perspective}

In 1924 Edwin Sutherland published the first edition of the now-classic Principles of Criminology. ${ }^{11}$ At the time Sutherland was an untenured assistant professor of sociology at the University of Illinois in Urbana. His education was also in sociology-receiving a Ph.D. from the University of Chicago in 1913. It may thus come as a surprise to learn of Sutherland's original position on the causes of crime. This is easy to miss, for criminologists today cite the later editions of Principles (see n. 2 above), in which the theory of differential association is laid out. But this strategy fails to reveal the magnitude of Sutherland's shift in thinking. The shift, ironically enough, was to come from a multiple-factor approach clearly stated in the first 1924 edition.

Although commonly viewed as a macrosociologist of cultural conflict (see, e.g., Kornhauser 1978), in 1924 Sutherland began by specifying what he considered to be the proper unit of analysis in criminology - the individual. As he noted, "knowledge can be secured best by the individual case study." $\mathrm{He}$ also argued for the comparison of "criminal and noncriminal populations" (1924, p. 86). Moreover, in an intriguing section of Principles entitled "Plan for Study of Causes of Crime," Sutherland outlines the "ideal" data-collection strategy in criminology. This would include "detailed records of the development of personalities," which "need to be very detailed and pursued from early infancy to old age" (1924, pp. 86-87). This strategy would also extend to "mental and

\footnotetext{
${ }^{11}$ It should be pointed out that, according to Gaylord and Galliher (1988), writing this text marked the beginning of Sutherland's career in criminology. His Ph.D. thesis focused on "Unemployment and Public Employment Agencies" and his overall substantive interests at the time seemed to be in areas of political economy and political science (Lindesmith 1988, p. xi).
} 
educational tests," as well as interviews with parents, teachers, and a full recording of all "conduct disorders." It is interesting that this is exactly the sort of methodological strategy followed by the Gluecks.

Sutherland was later to become vehemently antipsychiatry, but there was little evidence of this stance in his early writings on the substantive predictors of crime. For example, he noted the association between psychopathic personality and criminality and, in fact, argued that "there is good reason to believe that the psychopathic personalities, and especially those of the egocentric type, will get into difficulty with other people more frequently than the average individual" (1924, p. 123). Sutherland, like the Gluecks, also maintained that the family was a crucial variable in understanding delinquency: "Those homes with extremely rigid discipline, extremely lax discipline, or inconsistent discipline are developing many children with personalities that are socially undesirable and incline toward delinquency" (1924, p. 147). And, perhaps most ironic, Sutherland acknowledged openly the potential effects of biology on delinquency, noting possible mediating effects of social factors (1924, p. 180). Much like the Gluecks would later argue, Sutherland wrote that "it is not the physical defect itself that produces delinquency, but the social and other conditions surrounding the defective person" (1924, p. 180). In the 1920s Sutherland was thus a multiple-factor theorist. He in fact admitted as much, stating later in an address to the Ohio Valley Sociological Association, "I had a congeries of discrete and co-ordinate factors, unrelated to each other, which may be called multiple-factor theory" (in Schuessler 1973, p. 14).

Sutherland's favorable inclination toward the multiple-factor perspective also extended to his early communication with the Gluecks. The early correspondence between the Gluecks and Sutherland covered the period from February 26, 1929, to May 15, 1936. There are more than 40 pieces of correspondence over this time period. ${ }^{12}$ Our inspection of the full body of materials reveals a cordial relationship between professional colleagues. The topics of discussion included parole prediction and the role of mental defects and crime, among others. They also shared ideas and factual information. What is most noteworthy though is Sutherland's strong praise for the Gluecks' work. For instance, in response to the forthcoming publication of 500 Criminal Careers, Sutherland wrote, in a letter dated September 27, 1929, that the book was "a very great contribution to the literature and methods of criminology" (Sutherland 1929). In the same letter Sutherland did raise some points of "minor

\footnotetext{
${ }^{12}$ This correspondence can be found in the Eleanor T. and Sheldon Glueck Joint Papers and the Sheldon Glueck Papers, Harvard Law School Library, Cambridge, Mass.
} 
importance" with regard to statistical computations and the Gluecks' interpretation of research on parole prediction with respect to weighting factors. Overall, however, the tone of the letters was upbeat, and, as late as a May 4, 1936, letter, Sutherland praised the Gluecks and expressed "astonishment" at their publication record (Sutherland 1936).

The Gluecks in turn praised Sutherland's work. For instance, in 500 Criminal Careers (1930), the Gluecks discussed problems in major textbooks in the field with regard to assessment of recidivism rates. However, the Gluecks (1930, p. 7) noted that "E. H. Sutherland, in Criminology, does not fall into this fallacy of careless generalization in the direction of optimism." Similarly, with regard to Sutherland's second edition of Principles of Criminology, Sheldon Glueck's correspondence with Sutherland's publisher (J. B. Lippincott) stated that the text was "unquestionably the most satisfactory" on the subject and that Sutherland wrote with "objectivity," "temperateness," and "rational eclecticism" (S. Glueck 1934).

\section{SHIFTING TIDES: THE SUTHERLAND-GLUECK DEBATE}

Beginning in 1937, Sutherland began to shift his thinking and, as a consequence, his attitude toward the Gluecks' research. The buildup was slow at first and began with a review by Sutherland $(1937 b)$ of the Gluecks' Later Criminal Careers. The Later Criminal Careers (Glueck and Glueck 1937a) study was the second in a series focusing on 510 offenders released from the Massachusetts Reformatory. This particular book described the second five-year follow-up period after parole (192832). Sutherland's attention was centered largely on the two major conclusions of the study. First, improvement in behavior over time was attributed by the Gluecks "primarily to aging or maturation." And second, the major obstacle to reform through maturation was argued to be psychological dysfunction. Sutherland also critiqued almost every methodological aspect of the study, claiming, in a two-page review, that the information gathered was "scanty," that few of the offenders were "observed" firsthand, and that "the purpose of these studies has not been defined" (1937b, p. 185). His comments are interesting because an earlier study by the Gluecks (1930), identical in nature, had been praised by Sutherland (1934b, pp. 511, 546-47).

As to the substance of the findings, Sutherland strongly attacked the conclusion that "the reduction of delinquency was due to aging or maturation" $(1937 b$, p. 185). He unambiguously stated that "there is no justification for this conclusion, either in statistics or logic. Aging, as the mere passing of time, has no significance as a cause" $(1937 b$, p. 185). But Sutherland was even more perturbed by the Gluecks' psychologically 
oriented conclusion that mental and/or emotional difficulties impeded the process of reformation among former prisoners. Although as shown above he once agreed with this position, Sutherland argued that "this is the least satisfactory part of the book." He goes on to maintain in a few short sentences, and without documentation, that the psychiatrist at the institution (who made the evaluations before the follow-up when postrelease behavior was measured) had "a heavy case load and little time for careful examinations, and also had a general bias toward interpretation of delinquency as due to mental pathology" (1937b, p. 186). Ignoring the crucial fact that the classifications had predictive validity (Glueck and Glueck 1937a, pp. 127, 198-212), Sutherland dismissed the results ("no confidence can be placed in this") and the overall conclusions of the book, which he claimed "are doubtful" $\left(1937 b\right.$, p. 186). ${ }^{13}$

Despite its largely negative tone, Sutherland's review in the influential Harvard Law Review was only the tip of the iceberg. Sutherland's review was in fact culled from a longer, unpublished manuscript entitled "The Gluecks' Later Criminal Careers: An Appraisal by Edwin H. Sutherland" (1937c). This original paper was 18 pages in length and was circulated among criminologists, including the Gluecks. The paper was read at the annual meeting of the Sociological Research Association on December 30, 1937, in Atlantic City. ${ }^{14}$ An edited version was later published after Sutherland's death in The Sutherland Papers (Cohen et al. 1956, pp. 291-307). In the original piece, located in the Gluecks' archive at Harvard University, Sutherland critiqued in a forceful tone the Gluecks' conclusions regarding aging and maturational reform. He also began to express new views that foreshadowed his conversion to analytic induction (described in more detail below) as a methodological tool. With regard to the association between age and crime he wrote, "There is no statistical procedure by which a statistically significant association can be translated into a cause. ... Moreover, the passing of time no more explains reformation than it explains the genesis of a depression or the election of an old man to the Senate" (1937c, p. 12).

\footnotetext{
${ }^{13}$ For a published point-by-point response to the Sutherland review by a colleague of the Gluecks' from the Harvard Law School, see Hall (1937, pp. 389-93).

${ }^{14}$ According to correspondence from Sutherland to Eleanor Glueck on January 11, 1938, the session was chaired by Ernest Burgess and was devoted to a discussion of Later Criminal Careers based on papers by Sutherland and C. E. Gehlke. Sutherland wrote, "I read the principal parts of your paper to the group, reading at least twothirds of it" (1938). This statement was in response to a request in a letter to Sutherland from the Gluecks dated December 14, 1937: "If you plan to present your paper in its original form, we are sure you will do us the courtesy of having our reply read at the same meeting" (Glueck and Glueck 1937c). Whether the Gluecks actually expected Sutherland himself to read their reply to his critique of their book at a meeting organized to discuss their book is, to say the least, unclear.
} 
More generally, Sutherland expressed his distaste for the factual search for the correlates of delinquency in a longitudinal perspective. He argued that it was of utmost importance that researchers first present a thesis and then attempt to test it. Noting his disregard of the search for key facts, Sutherland followed up his unpublished critique with a letter, dated December 4, 1937. Sutherland wrote to Sheldon Glueck about Later Criminal Careers, "You would have been much safer if you had presented your factual data without the thread of theory, but in my opinion research work of that factual nature are safe but useless. Every research study should, I believe, be organized around general propositions or general theory, and unless it can be so organized it is relatively futile" $(1937 d)$.

It is interesting that this passage reveals that Sutherland recognized the Gluecks were not sheer empiricists. Indeed, in his longer review he refers to the Gluecks' "theory of criminal behavior" and that they "fail to prove their hypotheses" (1937c, p. 17). In any case, Sutherland castigated the collection of empirical data without theory, yet at the same time rejected the Gluecks' substantive framework on age and crime and maturational reform. Paradoxically, in fact, he accused the Gluecks of trying to prove a preconceived theory of persistent criminality (1937c, pp. 3-4).

The Gluecks were sufficiently concerned with Sutherland's critique that they responded (Glueck and Glueck 1937b) with a 25-page document that, to our knowledge, was never published. This response was titled "Analysis of Prof. Sutherland's Appraisal of Later Criminal Careers" and is dated December 13, 1937. It is surprising that the correspondence shows that some portion of the Gluecks' rejoinder was read by Sutherland himself at the 1937 meeting of the Sociological Research Association (see n. 14 above). In the response the Gluecks countered that they were not trying to prove any preconceived theories regarding age and crime: "We have no criminologic axes to grind. We search for facts as accurately as possible and on the basis of the findings we arrive inductively, and not $a$ priori, at certain conclusions. The statement from Later Criminal Careers that you quote on pages 3 and 4 [of the unpublished critique] is not a preconception with which we started our work; it is a theory suggested by the evidence emerging from the facts" $(1937 b$, p. 3$)$. In the full response they also answered, point by point, Sutherland's "minor" criticisms regarding the number of cases followed up as well as other issues. $^{15}$

${ }^{15}$ It is rather ironic to note that in the same year Sutherland was criticizing the Gluecks for their small sample size $(N=454)$, he published The Professional Thief (1937a), a case study of one. More generally, Sutherland conducted little, if any, 
They expressed more puzzlement, however, at Sutherland's views on methodology. In the Lazarsfeld tradition, the Gluecks tried to establish an age-crime relationship by ruling out (controlling for) other factors associated with age. Although admittedly crude by today's standards, the Gluecks' analysis was straightforward-after they had analyzed several competing variables, age and also psychological adjustment seemed to best predict desistance from crime. Their response to Sutherland reflects the Gluecks' general empirical stance:

\begin{abstract}
Your statement (page 12) that "there is no statistical procedure by which a statistically significant association can be translated into a cause" is a well known truism in a sense; but the illustration you give [age cannot explain the election of an old man to senate] is obviously absurd and is assuredly not analogous to the association of aging with behavior. While it is true that the mere association of two factors does not necessarily mean that one is causal of the other, it is also true that in every field of science an association between factors that ought, in reason and experience, to be related does give the basis of a valid inference as to causation. . . . If one could not ever make such an inference from statistical associations, it is hard to see how any science would be possible. [1937b, pp. 12-13]
\end{abstract}

They went on in great detail to argue that the age and psychological relationships with crime were robust and met the conventional methodological standards of the time.

One is thus led to wonder, as the Gluecks probably did, what exactly was responsible for Sutherland's newfound rejection of their work. We believe the answer lies in the confluence of three important factors relating to the changing socio-intellectual context of the late 1930s- $(a)$ analytical induction, $(b)$ sociological positivism, and $(c)$ the rising social position of Sutherland in the sociological profession.

\title{
Analytic Induction
}

According to Alfred Lindesmith, a colleague and close friend of Sutherland, subsequent editions of Sutherland's criminology text (in 1934, 1939, and 1947) sought to "improve and correct the multiple factor theory represented by the 1924 edition" (Lindesmith 1988, p. xi). Specifically, the 1939 and 1947 editions were "designed to substitute . . . differential association theory for that of multiple factors. . . During this same period Sutherland's reputation soared, and his criminological textbook

original empirical research on juvenile delinquency. Although presumably not intentional, this insulated his work from the sort of methodological criticisms aimed at the Gluecks. 
has dominated the field for more than half a century" (Lindesmith 1988, p. $\mathrm{xi}$ ).

A number of factors have been alluded to as being important in this transformation (see Schuessler 1973, pp. 13-29; Gaylord and Galliher 1988, chaps. 5 and 6). These include the publication of the Michael-Adler report (1933), which highly criticized existing criminological research; a meeting chaired by Dean Beardsley Ruml of the University of Chicago on the state of criminological knowledge, at which Sutherland could not state any positive generalizations about the causes of crime; Sutherland's work on The Professional Thief (1937a); the influence on Sutherland's thinking of the work of Charles $\mathrm{H}$. Cooley relating to social processes; the development of analytic induction by Alfred Lindesmith; Sutherland's collaboration with Thorsten Sellin for the Social Science Research Council and the subsequent publication by Sellin of Culture Conflict and Crime (1938); and finally, his colleagues at the University of Chicago and Indiana University.

Of these factors the most crucial from our perspective was the development of analytic induction by Alfred Lindesmith, a former student of Sutherland's at the University of Chicago. Lindesmith joined the Sociology Department at Indiana University in 1936 and became known for his research on drug addiction (Lindesmith 1947) and his new method of scientific inquiry. Sutherland succinctly noted the influence of Lindesmith and his methodological outlook.

When Lindesmith came to Indiana University . . . I became acquainted with his conception of methodology as developed in his study of drug addiction. According to this conception, an hypothesis should fit every case in the defined universe, and the procedure to use is: State the hypothesis and try it out on one case; if it does not fit the facts, modify the hypothesis or else redefine the universe to which it applies, and try it on another case, and so on for case after case. The methodology consists in searching for negative cases, one negative case disproving the hypothesis. Although this involves several cases, it is not concerned with averages, standard deviations, or coefficients of correlation. The methodology assisted me greatly in formulating problems and in testing hypotheses. [In Schuessler 1973, pp. 17, 18]

According to Gaylord and Galliher (1988), Sutherland had reached a theoretical impasse in the early 1930s-he was unable to make sense of multiple causes or factors and multiple-factor theory. Analytic induction provided Sutherland with a methodology that he believed allowed the development of a universal generalization that would explain all criminal behavior (Sutherland and Cressey 1955, pp. 68-69; see also Turner 1953). Specifically, this method led Sutherland to extract common elements and organize the heretofore diverse set of facts that criminological research 
had generated into the single theoretical abstraction of "differential association" (Gaylord and Galliher 1988, p. 116; Matsueda 1988, pp. $277-80) .{ }^{16}$

Moreover, by embracing analytic induction as the scientific method, Sutherland's development of a general theory of crime causation included a rejection of multiple-factor theory as, among other things, unscientific. As a result the Gluecks' methodology as well as their substantive interest in multiple factors of crime causation were dismissed by the new Sutherland perspective. This conversion is clearly seen in the 1947 edition of Principles of Criminology, in which Sutherland argued (p. 3) that "any scientific explanation consists of a description of the conditions which are always present when a phenomenon occurs and which are never present when the phenomenon does not occur."17

One can argue that Sutherland had adopted what Hirschi and Selvin (1970) have termed "the false criteria of causality." In large measure, Sutherland's critique of multiple-factor approaches generally, and the Gluecks' research specifically, rests on "false criterion 1." "Insofar as a relation between two variables is not perfect, the variable is not causal" $(1970$, p. 129). The implication of this point is striking. "Perfect association implies single causation, and less-than-perfect association implies multiple causation. Rejecting as causes of delinquency those variables whose association with delinquency is less than perfect thus implies rejecting the principle of multiple causation" (Hirschi and Selvin 1970, p. 130). As they argued, this criterion of noncausality is inappropriate. ${ }^{18}$ In a somewhat different vein, Turner (1953) argues that studies using analytic induction fail to provide empirical prediction.

\footnotetext{
${ }^{16}$ According to Sutherland, criminal behavior, like noncriminal behavior, is learned in interaction with other people: "A person becomes delinquent because of an excess of definitions favorable to violation of law over definitions unfavorable to violation of law" (Sutherland and Cressey 1955, p. 78). Sutherland also strongly emphasized culture in his analysis of crime, arguing that society consisted of a number of diverse groups with varied cultures. Underlying the phenomenon of criminal behavior is the principle of culture conflict, which leads to differential association, which in turn leads to criminal behavior (see also Matsueda 1988). Sutherland eventually developed nine propositions of differential association (see Sutherland and Cressey 1955, pp. 77-79).

${ }^{17}$ During the 1950s Albert Cohen, a student of Sutherland, also wrote a sharp critique of multiple-factor theory (Cohen 1970). See Hirschi and Selvin (1970) and Hirschi (1973) for a response to Cohen's critique.

${ }^{18}$ Hirschi and Selvin (1970, p. 130) note that precedent for demanding the "perfect criterion of causality" can be found in Michael and Adler's (1933) critique of criminological research. This report was influential in shaping Sutherland's thinking about criminological theory and research (Gaylord and Galliher 1988).
} 
With respect to the notion of cause, the Gluecks "recognized that certain influences may be regarded as causal in a statistical sense of high probability" (Glueck and Glueck 1974, p. 44; 1952, pp. 164-69) and thus followed a widely accepted probabilistic model of social science methodology - that is, association, causal order, and lack of spuriousness (see Hirschi and Selvin 1967). (For an illustration of their use of cause see Unraveling [1950a, pp. 281-82].) In sharp contrast, Geis and Goff have noted that "it was one of Sutherland's favorite statements that ' 85 percent of anything could not be a cause. It had to be 100 percent or it was not a theory.' Indeed, if poverty didn't always cause crime, then poverty couldn't qualify as part of a theoretical causal statement" (1986, p. 9).

It is difficult to overestimate the significance of Sutherland's scientific view for the field of criminology. As Hirschi has highlighted, "Perhaps the outstanding event in the intellectual history of theories of cultural deviance was not a decision about the nature of man, but a rather ordinary appearing decision [by Sutherland] about the nature of scientific explanation: 'I reached the general conclusion that a concrete condition cannot be a cause of crime, and that the only way to get a causal explanation of criminal behavior is by abstracting from the varying concrete conditions things which are universally associated with crime.' Sutherland decided that every case of crime should be explained by the theory he proposed to construct" (1969, pp. 13-14). As Hirschi points out, Sutherland's view that "only concepts can be causes leads to misinterpretation of empirical results and ultimately to the view that the quest for causes is futile" (1969, p. 13, n. 38; see also Hirschi and Selvin 1967, pp. 130-33, 177-83). Although some readers will certainly disagree with the Hirschi-Selvin position on criteria of causal research, it is nonetheless the case that virtually no empirical research today in criminology is guided by analytic induction.

\section{Sociological Positivism}

A second, and equally important, factor in explaining Sutherland's changing conception of theory was his use of a particular form of sociological positivism. Traditionally, when social scientists think about positivism there is a tendency to focus on issues of cause and effect, empirical data, replication, and public statement of research methods. In this sense positivism does not fix the concepts to be used in explanations of phenomena, and it guarantees success to none of its constituent disciplines (Gottfredson and Hirschi 1990, p. 49). However, Gottfredson and Hirschi go on to argue that positivism as practiced in the 20th century has actually 
been used as a substantive perspective as well as a method of knowing. Specifically, the major error of modern positivism has been the "tendency to confuse the interests of one's discipline with the interests of scientific explanation" (1990, p. 73). In the study of crime, for example, they are able to document the proprietary interests of biology in heritability, psychology in personality, and sociology in social class (Gottfredson and Hirschi 1990, chaps. 3-4). They argue that, by fusing positivism with such "a priori" concepts, the rival disciplines virtually require that research outcomes be consistent with their estimate of their own importance in the behavior at issue.

Nowhere is this more true than in understanding why Sutherland deemed it necessary to attack the Gluecks' work. The Gluecks were gaining widespread readership and, with the exception of Sutherland, praise.$^{19}$ More important, Sutherland saw the multiple-factor approach, with its inclusion of such individual-level factors as age and mental capacity, as a threat to a substantive version of sociological positivism. As Gottfredson and Hirschi argue, "Criminology, which came to be dominated by sociology, eventually saw the destruction of individuallevel correlates as a prerequisite to 'truly social' theorizing" (1990, p. 70, n. 3). Thus, sociological positivism as practiced by Sutherland did not attempt to establish the sociological causes of crime independent of individual-level factors in the Durkheimian tradition. Rather, crime was viewed by Sutherland as a social phenomenon that could only be explained by social (i.e., nonindividual) factors. As a result, Sutherland "explicitly denied the claims of all other disciplines potentially interested in crime" (Gottfredson and Hirschi 1990, p. 70). ${ }^{20}$

When combined with Sutherland's adoption of analytic induction, it was then possible for him to interpret all phenomena in a manner consistent with a pure sociological theory of differential association (see also Matsueda 1988). As Hirschi and Gottfredson have argued elsewhere, "Sutherland invented or adapted standards of scientific adequacy that

\footnotetext{
${ }^{19}$ For example, Walter Reckless, a noted sociologist at Ohio State University, argued in a review of Juvenile Delinquents Grown $U p$ that the Gluecks were "pre-eminent in this field of research" (1941, p. 736). Although critical of key aspects of the Gluecks' research, Reckless concluded that, "in spite of shortcomings which inevitably greet pioneer attempts at forecasting, the Gluecks' persistence in their endeavor to explain and to predict criminal outcome by the method of factoring is courageous and praiseworthy" (p. 738). Similarly, Donald Taft, a sociologist at the University of Illinois, wrote in a review of Later Criminal Careers that "this valuable book . . . illustrate(s) the importance of long-time criminological research" (1937, p. 940). Further, Taft emphasized the "painstaking type of research which the Gluecks-more than any other investigators-are furnishing" (p. 941).

${ }^{20}$ Sutherland even went so far as to express regret that nonsociologists received funds for research in criminology (see Cohen et al. 1956, p. 270).
} 
permitted an ad hoc interpretation of research findings in ways consistent with the theory of differential association" and thus that "the genius of Sutherland . . . was that as he produced a theory of criminality, he simultaneously produced a science to protect it from research results and from competitive theories" (1980, p. 10). This model effectively insulated Sutherland's theory from the results of empirical research based on a multiple-factor approach by defining the necessary and sufficient causes of crime. Hence, with the 1939 edition of Principles as a backdrop, criminology became a field closed to the possibility that disciplines other than sociology might have something to contribute (Gottfredson and Hirschi 1990, p. 70).

It is important to recognize here that the error of positivism when interpreted as a substantive theory of crime was not sociology's alone-it was embraced by biology, psychology, and economics as well. The difference, however, is that sociology was successful in its attempt to take over the study of crime (for details, see Gottfredson and Hirschi [1990]; and Gaylord and Galliher [1988]). ${ }^{21}$ Sutherland's leadership role in this action was widely recognized - so much so that Robert Merton even compared Sutherland's Principles of Criminology to such disciplinary classics as Samuelson's Economics and Gray's Anatomy as books that "leave an enduring impress on generations of students" (1971, p. vii).

\section{Defending the Sociological Perspective}

That Sutherland became the warrior for sociology's coup of criminology was also linked to his social position and rising influence in the sociological discipline. In 1935 he moved from the University of Chicago to Indiana University as head of the Department of Sociology. Exercising a leadership position there, he went on to become president of the American Sociological Association in 1939. In 1940 he was elected president of the Sociological Research Association. He was also elected president of the Ohio Valley Sociological Society in 1942.

As argued in a recent paper by Galliher and Tyree (1985, p. 111), Sutherland was driven by a strong "anti-psychiatry ideology," and he saw this issue as a "professional turf" concern in making the case for a sociological criminology with himself as its leader (see also Gaylord and

\footnotetext{
${ }^{21}$ In this regard it is interesting to note Sheldon Glueck's bitter and hostile reaction: "The most confident and severest critics have been a group whose writings have the tone of fire-breathing chevaliers eager to do battle for that purest queen of the exact sciences, Sociology, to which the authors of Unraveling Juvenile Delinquency allegedly did not pay adequate tribute" (1960, p. 284). The Gluecks clearly did not take criticism well.
} 
Galliher 1988; and Goff 1986). Sutherland's intentions were not lost on his contemporaries either. As his former colleague Karl Schuessler writes, Sutherland had a "bias against psychiatry" $(1973$, p. xvii) and "did not broaden his theoretical model to accommodate biological and psychological factors. In fact, he was severely critical of those criminologists who stretched their framework to include every possible factor, however disparate those factors might be" $(1973$, p. x). Clearly, it came to serve both Sutherland's interests and those of the discipline to establish proprietary rights in the study of crime.

There is also little doubt that Sutherland accurately perceived his own role in spearheading the sociological undermining of the Gluecks. Indeed, in a manner destined to embitter the Gluecks, Sutherland alone reviewed almost all of their books in professional journals (mainly law reviews) in the 1930s and 1940s. In a letter to Sheldon Glueck dated February 11, 1944, Sutherland even wrote, "I refused three invitations from journals to review your Criminal Careers in Retrospect because I did not desire to acquire an institutional status as a critic of your work." However, he goes on to say that he did in fact write the review when he "felt that it would be possible to write a review which would be relatively formal" (1944b).

His 1944 letter also continued the dismissal of individual-level correlates of crime that was consistent with the new outlook of the 1939 edition of Principles. While writing to Sheldon Glueck to "assure you that I have a most kindly personal attitude toward you," he went on to criticize the relevance of age to crime, arguing that the relationship was only "slightly more than chance." Sutherland also attacked the Gluecks' long-standing hypothesis concerning the stability of antisocial behavior over the life course. In particular, he contradicted his 1924 book and argued that "I believe that you do not demonstrate that these childhood characteristics have more than a slight relationship to behavior in middle age" $(1944 b$, p. 2). In fact, Sutherland repeated his earlier charge that this "was a preconception and not a finding" (1944b, p. 2; see also Sutherland's formal review [1944a]).

In addition, Sutherland placed the Gluecks' research in the same camp as William Sheldon and E. A. Hooton, two researchers at Harvard interested in the biological causes of human behavior (see Cohen et al. 1956, pp. 270-326). The result was that the Gluecks were perceived as being interested in only the biological basis for criminal behavior. It is no surprise, then, that the most controversial aspect of the Gluecks' research vis-à-vis sociology was their inclusion of constitutional factorsespecially body structure-in the study of crime. Indeed, sociologists have always had a long-standing aversion to biological explanations of human behavior. As Rowe and Osgood note, "In most sociological treat- 
ments of crime and delinquency, genetic explanations are either ignored or ridiculed" (1984, p. 526).

Ironically, however, the Gluecks never posited a deterministic biological model. They argued instead that biological features set the context for social forces. That is, the Gluecks were interested in how social factors mediated the undeniable differences among individuals in such crimerelevant characteristics as strength. As Sheldon Glueck argued, "Those criminologists who call attention to variations in the strength of different hereditary drives and controlling mechanisms do not claim that criminalism per se is inherited, but merely point to the too-often sociologicallyunderemphasized if not ignored biological fact that, in the eyes of nature, all men are not created equal and that some, because of certain traits useful to the kind of activities involved in criminal behavior, probably have a higher delinquency potential than others" (1956, p. 94).

Sutherland also failed to recognize that the Gluecks were as critical of the work of Sheldon as was Sutherland himself. For example, in a review of Sheldon's Varieties of Delinquent Youth (1949), the Gluecks stated, "Space limitations do not permit us to illustrate [the] deficiencies . . . in the work under review" with respect to standard canons of science $(1950 b$, p. 215$)$. The Gluecks went on to totally dismiss the conclusions made by Sheldon, in large part because of an inadequate sampling design (1950b, p. 215). In a similar manner, Sutherland (1951) argued that Sheldon's research methods were suspect and his research failed to establish the physical differences between offenders and nonoffenders. In particular, Sutherland, like the Gluecks, pointed out that the "manner of selecting cases . . . effectively prevents [Sheldon] from reaching valid conclusions regarding delinquency" (1951, p. 10). Thus, not only was Sutherland's equation of the Gluecks with biological determinists such as Sheldon and Hooton (see, e.g., Sutherland and Cressey 1978, pp. 123-24) an error of sociological positivism, Sutherland's wholesale rejection of biological influences on human behavior appears to be at odds with current knowledge (see esp. Rowe and Osgood 1984; Udry 1988; Cohen and Machalek 1988).

Sutherland's final and probably most severe attack on the Gluecks concerned forms of data collection and analysis. Quite simply, Sutherland went so far as to imply that the Gluecks fudged their data. His claim was expressed in several ways. In a published review he implied that the Gluecks used ex post facto psychiatric evaluations and thus that the mental diagnosis was "necessarily" associated with the behavior (Sutherland 1937b, p. 186). More damning were "informal" comments made in the 1937 review circulated among colleagues across the country. He stated, "When the data and methods are examined, they are found to be completely untrustworthy" (1937c, p. 14), and he specifically charged 
that the Gluecks "must have made their classification after the delinquency or nondelinquency of offenders during the second period was already known to them, as well as after the failure to meet economic or family responsibilities and the other aspects of behavior during the second period were already known to them. The classification is therefore nothing except an expression of the authors' a priori conception of the relationship between overt behavior and mental condition. Nothing except clerical errors could have prevented a high correlation between mental abnormality and persistence in criminal behavior" (1937c, pp. 15-16). With this alleged fatal flaw, not only could the Gluecks' data be dismissed, but their entire substantive framework, as judged by Sutherland, "breaks down completely" (1937c, p. 17).

The Gluecks appeared quite aware of the underlying message of Sutherland's criticisms. As they wrote in their 25-page rejoinder, "You distinctly imply that we have somehow manipulated our materials to get the result for which we were looking from the beginning. This is a very serious charge to make and we are wondering how you could possibly have arrived at it. It is very startling, to say the least, that . . . you could infer that we manipulate our materials" $(1937 b$, p. 20). The Gluecks argued that the charge ought to be "ignored as undeserving of notice," but since Sutherland had, in their words, the "temerity" to make it $(1937 b$, p. 20$)$, they countered with the obvious fact that Sutherland ignored: "It seems quite self-evident that the psychiatrists who made the examinations at the different hospitals throughout the country at different times and without the knowledge that the Gluecks would come along, many years later, and make follow-up studies did not conspire with us beforehand to see that the unreformed would have a higher incidence of mental deviation than the reformed. They could not possibly have known, when they made the examinations, which of the men would many years later turn out to be recidivists and which would reform" $(1937 b$, p. 20). The rest of their response rebutted in detail the thrust of Sutherland's criticisms.

Sutherland's tenaciousness in striving for a pure sociological reading of the evidence extended to his own work as well. For example, in a detailed examination of the origins and development of Sutherland's The Professional Thief (1937a), Snodgrass argues that "Sutherland overestimated the class-origin of the professional thief" and "virtually ignored . . . Jones' addiction to narcotics" (1973, pp. 11, 13). Snodgrass's evaluation of this can be interpreted as Sutherland's use of a misguided sociological positivism:

A possible, but perhaps uncharitable, explanation for this omission might be the common theoretical association of drug dependence with psychological maladjustment. Sutherland's sociological interpretation would have 
been considerably weakened, or at least challenged, had he revealed to the reading audience that professional thieves were often "dope fiends," as they were known then, who shot-up with the drugs obtained from the money earned in their work. Sutherland was with this book also opposing the psychological school by attempting to picture thieves as mentally stable. Evading the drug issue was perhaps a way of supporting his sociological explanation and avoiding a psychological controversy. [1973, p. 15]

Similarly, Galliher and Tyree (1985) examined Sutherland's research on the origins of sexual psychopath laws and found that he ignored evidence contrary to his hypothesis. Moreover, Galliher and Tyree discovered "curious lapses and inconsistencies in the evidence he [Sutherland] marshaled in support of his conclusions" (1985, p. 100). More specifically, they argue (1) that Sutherland did not systematically review the newspapers from the states he discussed, (2) that his conclusions about the press were based on a very selective sample of sensationalistic pieces, especially lurid magazine articles, and (3) that he ignored critics such as Tappan, Inbau, and Gault who questioned his claims. The selective attention to facts was attributed to Sutherland's strong "antipsychiatric ideology" (1985, p. 110).

We emphasize that, in our view, Sutherland was not driven by individual maliciousness or intentional dishonesty in his own work or in his attack on the Gluecks. Rather, Sutherland's behavior may be seen as socially conceived by the factors analyzed above-a substantive version of sociological positivism fused with a false criterion of causality supplied by analytic induction. In conjunction with his rising social position as the leading sociologist of crime, it seems less surprising that Sutherland selectively interpreted evidence in the process of dismantling the competition. In fact, it seems fair to suggest that Sutherland actually believed the Gluecks' data had to be wrong and the sociological perspective portrayed in the idea of differential association right. ${ }^{22}$

\section{THE TRANSMISSION OF ACCEPTED WISDOM}

Despite the unproven nature of Sutherland's charges against the Gluecks, the damage was done and took on a life of its own that remains to this day in sociology. The momentum was facilitated in large part by the social and institutional context within which both parties operated. Hav-

\footnotetext{
${ }^{22}$ It is beyond the scope of this paper to evaluate the research bearing on the validity of differential association theory. Besides, this has been done elsewhere-for excellent arguments that take opposing views see Kornhauser (1978) and Matsueda (1988). It will come as no surprise to learn that the Gluecks did not think much of differential association. At one point Sheldon Glueck referred to the idea of differential association as "puerile" and as a "roof without a house" (1956, pp. 92, 99).
} 
ing access to the benefits offered by a graduate sociology department, Sutherland became something of a magnet for Ph.D. students who would go on to carry the torch of differential association theory and a disregard for the Gluecks' research. In particular, Donald Cressey was a student of Sutherland's at Indiana University who later coauthored six editions of Principles. But there were also other prominent graduate students such as Albert Cohen and Lloyd Ohlin who were deeply influenced by Sutherland. As Cohen remarked in an interview with Laub (1983) about Indiana University in the late 1930s, at the height of the SutherlandGlueck debate, "I would say all of the better graduate students were in criminology. They were all studying with Sutherland. There was a sense that the department of sociology at that particular time was really the breeding ground of theory. You were there at the source. The most exciting things in criminological theory were happening right there and they all somehow had to do with differential association. Differential association was theoretically the end of the world" (Laub 1983, p. 186). Cohen's remarks seem entirely apt in describing Sutherland's dedication to differential association and inculcating a generation of students that would do likewise. Indeed, Cohen noted that Sutherland "functioned as a kind of a guru" (Laub 1983, p. 186).

The Sutherland mystique even extends to the imputation of laudatory motives on the part of Sutherland in his judgments of the Gluecks. For example, Snodgrass has written that "Sutherland's obsession with honesty is no small reason for why he got into such a fracas with the Gluecks" (1972, p. 227). Schuessler writes that "he [Sutherland] was uncanny in his ability to spot errors in statistical logic and patient in locating the trouble-witness his unraveling of the Gluecks" (1973, p. xxxv). Similarly, Geis and Goff note that Sutherland's "writings are unsparing in their exposure of false syllogism, sloppy logic, the unsupported inference, and the generalization rooted in infancy rather than fact" (1983, p. xxi). Finally, Snodgrass (1972) argues that in his review (1934b) of One Thousand Juvenile Delinquents Sutherland "was one of the first to point to the Gluecks' exaggerations and omissions of data," and he goes on to state, without any documentation, that this is "a charge which has subsequently been repeated and enlarged, and a fact which might insure that [the Gluecks'] research will come to be discredited, if not disregarded, by future students and historians of the discipline" (1972, p. 244; emphasis added).

At the same time, key aspects of the Gluecks' perspective as well as their own particular institutional/historical context also contributed to their demise. We have identified six specific reasons why sociology, especially after Sutherland's death in 1950, was so hostile to the Gluecks' work. First, the Gluecks had a tendency to infuse their works with moral 
statements that reflected middle-class biases. For instance, in regard to the management of income, the Gluecks wrote that families of delinquents were "living from day to day, borrowing without thought of their ability to make reimbursement and showing little comprehension of the value of limiting their expenditures to conform to a meager income" (1950a, p. 108). On all accounts, the Gluecks simply viewed delinquents and their families as inferior. Moreover, although the Gluecks' data were derived from multiple reports describing actual behaviors, the Gluecks often injected moral judgments in their summary coding scheme using categories such as good, fair, and poor to describe these behaviors (see Glueck and Glueck [1950a] for numerous examples).

Second, as mentioned above, the Gluecks were atheoretical in their approach to the study of crime. But more than that, the Gluecks were antitheory. Although they emphasized an empirical tradition and sought to identify any and all characteristics that may be related to crime and delinquency, they regarded abstract theory as idle speculation and not useful from a scientific view. Thus, the Gluecks did not present a theory of crime or even any systematic theoretical ideas in their numerous works. In fact, their idea of a theoretical statement was to present a "tentative causal formula or law" that merely summarized their findings distinguishing offenders from nonoffenders (see Glueck and Glueck 1950a, pp. 281-82).

Third, despite embracing a multiple-factor approach, the Gluecks downplayed or ignored traditional sociological variables like stratification, peer group, culture, and community characteristics. As Snodgrass has noted (1972, p. 9), the Gluecks' focus was "bio-constitutional and psycho-social." Specifically, the Gluecks downplayed social factors (e.g., delinquent associates) in favor of morphology, temperament, and early family influences (see Glueck and Glueck 1943, p. 69; 1950a; 1956; 1962; 1968, p. 170). Overall, the Gluecks' research reflected a restricted range of interest in key sociological variables presumed to be related to crime.

Fourth, recall that Sheldon Glueck was a law professor and Eleanor Glueck a soft-money research assistant. By function of their social position within the academic institution, the Gluecks were precluded the opportunity to train graduate students and develop the sort of following that Sutherland had. Quite simply, no one had a stake in defending the Gluecks. We believe this context is crucial in understanding the transmission of Sutherland's legacy.

Fifth, our review of the Glueck papers, especially their personal correspondence (i.e., notes and letters), leads to the conclusion that the Gluecks suffered from social awkwardness and a severe difficulty in public relations. Whereas Sutherland was well liked and perceived to be "humble" and "gentle" (see Laub's [1983] interviews with Cressey, Co- 
hen, and Ohlin), the Gluecks were stubborn and pompous and had great difficulty accepting any criticism of their work, justified or not, as something other than a personal attack on their integrity (see also S. Glueck 1960). This no doubt impeded their attempts to establish a cadre of supporters.

Sixth, and perhaps most important, the Gluecks' research was driven by pragmatic concerns. More precisely, they sought to influence social policy through the use of their prediction tables in two distinct ways. One was to improve the process of decision making by judges, probation officers, parole boards, and military officials. ${ }^{23}$ The second was to identify potential delinquents at school age or perhaps even as early as age two and three (see E. Glueck 1966; and Glueck and Glueck 1959) in order to provide therapeutic intervention. For example, the Gluecks argued that the selection of potential delinquents at an early age "would make possible the application of treatment measures that would be truly crime preventive" (1950a, p. 257). Moreover, the Gluecks promoted this interest in the popular literature as well as in scholarly books and journals (see, e.g., Glueck and Glueck 1952; Morgan 1960; Callwood 1954; and Dressler 1955).

The Gluecks' research on prediction has been severely criticized on methodological grounds (see, e.g., Reiss 1951; Hirschi and Selvin 1967; and Laub and Sampson 1988). However, this interest reflected their professional interests and intellectual history. Although at the time sociology was not explicitly linked to social policy, such practical applications were the norm for the discipline reflected in the background of the Gluecks-law, psychiatry, education, and social work. In addition, this pragmatic orientation was consistent with the interests of the Gluecks' mentors such as Bernard Glueck and William Healy. Thus, through their interest in prediction techniques, the Gluecks promoted an emphasis on individual-level analysis and advocated the penetration of psychiatric expertise into the formal systems of social control. In fact, Sheldon Glueck maintained that "dynamic psychiatry offers the greatest promise of any single discipline for the discovery of the complex causes and motivations of emotional, intellectual, and behavioral maladjustment and for developing effective prophylactic and therapeutic techniques. For the psychiatric approach necessarily deals with the blended interplay of the forces of nature and nurture, instead of grossly overemphasizing innate predisposition, on the one hand, or external environment and general cultural influences, on the other" (1962, p. 158).

\footnotetext{
${ }^{23}$ For an overview of prediction research in the criminal justice area, see Glueck and Glueck (1959); for an application of the prediction tables in the military, see Schneider et al. (1944).
} 
The Gluecks even envisioned a criminal justice system based on "the rational exercise of discretion enlightened by the reports of psychiatric, psychological, and social workers who ought . . . to be indispensable adjuncts to criminal courts and to classifying agencies and correctional establishments" (S. Glueck 1962, p. 139). Furthermore, the Gluecks encouraged the use and expansion of court clinics and child guidance centers. The result of this concern with social policy and the explicit promotion of the professional interests of the field of psychiatry was to further alienate the Gluecks from mainstream sociology as reflected by the works of Sutherland. ${ }^{24}$

Having placed the Sutherland-Glueck debate in social and historical context, we now turn to a brief assessment of the Gluecks' legacy. If Sutherland and common wisdom are correct (see also Snodgrass 1972, p. 244), then the Gluecks' research should have long ago faded into irrelevance. As it turns out, it is not even necessary to rely on the Gluecks' own defense to show the exaggerated nature of Sutherland's critique. Indeed, it is ironic that, despite numerous personal flaws and narrowly conceived professional interests, the Gluecks' substantive research in criminology remains strong.

\section{A REVISIONIST ASSESSMENT OF THE GLUECKS' RESEARCH}

The Gluecks could not have known the implications of their work for modern criminology. To speak of their "contributions" to present research is thus, as shown by Jones (1977, pp. 282-89), to commit the error of "presentism." We avoid this tendency by assessing the validity of their research methodology and substantive conclusions-that is, do they stand up to external verification? Moreover, to the extent that the current research agenda in criminology is simply an unacknowledged version of the Gluecks', the validity and importance of their work is further increased. Our assessment is based on a brief overview of four fundamental claims made by the Gluecks that, as detailed above, were dismissed by Sutherland.

Age and crime. - In a recent and highly cited article in this Journal, Hirschi and Gottfredson (1983) have argued that the age-crime relationship is one of the strongest in criminology and is generally invariant across time and space. Specifically, Hirschi and Gottfredson have con-

\footnotetext{
${ }^{24}$ It should be pointed out that the Gluecks' research was well received and respected in European countries (Snodgrass 1972, p. 330). This may reflect the fact that, historically, European criminology was dominated by the legal and medical professions in contrast to the United States where criminology was dominated by sociology (see Mannheim 1972, p. 2).
} 
tended (see also Gottfredson and Hirschi 1986) that crime declines with age and that this pattern holds true even for the most active offenders (career criminals). Their evidence is based on a comprehensive review of extant data on the age-crime relationship covering many different cultures and time periods.

Whether or not the age-crime curve is "invariant" across time and space, the research literature clearly shows that the Gluecks were correct about the fundamental importance of age, and that their evidence collected over 40 years ago remains some of the best available on the subject. As Gottfredson and Hirschi concluded, "The Gluecks' data are corroborated by other sources" (1988, p. 50, see also pp. 39, 49). Even the most vocal critics of Hirschi and Gottfredson agree, unlike Sutherland, that age is an important predictor of crime and have also turned explicitly to the Gluecks' data for insight (see, e.g., Blumstein, Cohen, and Farrington 1988, pp. 12-13).

Criminal careers and longitudinal research. - The field of criminology is currently embroiled in a bitter dispute over the value of longitudinal research and the criminal-career paradigm. The spark for this dispute was the publication of a recent report by the National Academy of Sciences (NAS; Blumstein et al. 1986) wherein it was concluded that longitudinal research was necessary to study the causes of criminal careers. Moreover, the NAS report called for major new research initiatives to estimate four parameters of the criminal-career paradigm: participation (the distinction between those who engage in crime and those who do not), frequency (the rate of criminal activity of those who are active), seriousness of offenses committed, and career length (the length of time an offender is active). It is argued that valid estimates of these parameters are needed to determine effective crime-control policies in terms of selective incapacitation and individual deterrent effects (Blumstein et al. 1986, pp. 202-4). However, Gottfredson and Hirschi (1986, 1987, 1988) have forcefully attacked the NAS report, basically by claiming that longitudinal research is unnecessary and that selective incapacitation is impossible to achieve.

It is much beyond the scope of this paper to resolve the debate over longitudinal research and criminal careers. However, it is not necessary to do so to acknowledge that the Gluecks were the first to systematically put forth the criminal-career paradigm. As noted earlier, the Gluecks originally made the distinction between frequency and participation, arguing that the causes of recidivism were different from the causes of onset (Glueck and Glueck 1930, 1934a, 1945). They were also the first criminologists to collect longitudinal data on a large scale, follow offenders over long periods of time, study career length, and, unbeknownst to 
most, suggest the policy of selective incapacitation (Glueck and Glueck 1945, pp. 106-8; 1968, p. 166).

In short, regardless of whether one agrees with the current emphasis in criminology on criminal-career research and longitudinal designs (for opposing viewpoints, see Blumstein et al. [1988] and Gottfredson and Hirschi [1988]), there can be little doubt that such an emphasis basically revives the Gluecks' original arguments. In point of fact, the most adamant critics of the criminal-career paradigm attribute its origin to the Gluecks (see Gottfredson and Hirschi 1988, p. 39).

Stability of crime and deviance. - One of the Gluecks' early and major contributions to criminology was their hypothesis of stability of crime and deviance across the life course. Unlike Sutherland, who saw criminality as an ever-changing construct dependent on changing social influences, the Gluecks documented the relative stability of betweenindividual differences in crime. The Gluecks' hypothesis can be seen as one of "longitudinal consistency," which concerns "the extent to which individuals in a group retain their relative position on a certain dimension or characteristic . . . at different points in time" (Olweus 1979, p. 852). As they argued in a section of Delinquents and Nondelinquents in Perspective aptly titled "The Past Is Prologue," "while the majority of boys originally included in the nondelinquent control group continued, down the years, to remain essentially law-abiding, the greatest majority of those originally included in the delinquent group continued to commit all sorts of crimes in the 17-25 age-span" (Glueck and Glueck 1968, p. 170). In a related argument, the Gluecks' also hypothesized that early life experiences had strong effects on crime in the adult years.

What do the data say? The evidence on longitudinal consistency is unequivocally clear - antisocial behavior is a remarkably stable phenomenon (Loeber 1982; McCord 1979; Robins 1966; Olweus 1979; Huesmann et al. 1984; Gottfredson and Hirschi 1990). For example, Olweus reviewed over 16 studies on aggressive behavior and found "substantial" stability. More precisely, the correlation between early aggressive behavior and later criminality averaged .68 for the studies reviewed (Olweus 1979 , pp. 854-55). Loeber completed a similar review of extant literature in many disciplines, concluding that a "consensus" has been reached in favor of the stability hypothesis: "Children who initially display high rates of antisocial behavior are more likely to persist in this behavior than children who initially show lower rates of antisocial behavior" (1982, p. 1433). In probably the most influential study of its kind, Huesmann et al. (1984) studied the aggressiveness of 600 subjects, their parents, and their children over a 22 -year period. They concluded that "early aggressiveness was predictive [correlation of .50 for males] of later serious 
antisocial behavior, including criminal behavior, spouse abuse, traffic violations, and self-reported physical aggression. Whatever its causes, aggression can be viewed as a persistent trait that may be influenced by situational variables but possesses substantial cross-situational constancy" (1984, pp. 1120, 1128).

Finally, McCord (1979) and Robins (1966) demonstrated the powerful effects of early-life experiences on later adult behavior. In fact, McCord showed that predictions of adult criminality based on childhood family experiences were more accurate than predictions based on the individuals' juvenile criminal records (1978, p. 1485). Sutherland's protestations notwithstanding, the Gluecks' early hypothesis of stability, later confirmed in Delinquents and Nondelinquents in Perspective (Glueck and Glueck 1968), has itself been confirmed by an impressive body of interdisciplinary research.

Social control, the family, and delinquency.-Hirschi's (1969) influential Causes of Delinquency stated the now widely cited reformulation of assumptions about human nature implicit in differential association theory. As he argued, the question is not why do they do it, but rather "Why do men obey the rules of society: Deviance is taken for granted; comformity must be explained" (1969, p. 10). Consider now Sheldon Glueck's earlier conceptualization of the problem, which also directly contradicts differential association theory: "What is there to be learned about simple lying, taking things that belong to another, fighting, and sex play? . . . One must conclude that it is not delinquent behavior that is learned; that comes naturally. It is rather non-delinquent behavior that is learned. . . . Law-abiding character formation is a hard-won process" (1956, pp. 94-95). The Gluecks were thus early proponents of a socialcontrol perspective, arguing that the child must be socialized to overcome natural asocial or antisocial impulses. Although unsystematic, the Gluecks' notion of social control led them to study the role of families, schools, opportunities (e.g., peers and use of leisure time), and formal sanctions in explaining crime and delinquency.

Of all the factors they studied, however, the Gluecks clearly focused most attention on the family. They identified the key predictors of delinquency as inconsistent and/or lax disciplinary practices by parents, low supervision and monitoring of the youth's behavior, and attenuated attachment between parent and child (1950a, p. 261). These same family process factors have subsequently been shown to be sturdy and strong predictors of juvenile delinquency in a variety of settings-including different time periods, geographic location, age groups, and methodology (see esp. Farrington and West 1981; Robins 1966; Hirschi 1969; Patterson 1982). And in the most exhaustive review available on families and crime, Loeber and Stouthamer-Loeber $(1986$, pp. 37, 120) conclude that "as- 
pects of family functioning involving direct parent-child contacts" are the most powerful predictors of delinquency and other juvenile conduct problems.

We have also reanalyzed the raw data from the Gluecks' Unraveling Juvenile Delinquency from the vantage point of $(a)$ recent theoretical advances on the family (e.g., Hirschi 1969, 1983; Patterson 1982) and (b) recent advances in multivariate techniques. The results (see Laub and Sampson 1988) demonstrate that the strongest predictors of delinquency are the same family variables identified by the Gluecks as the most important correlates of delinquency over 30 years ago-discipline, supervision, and attachment. Not only do these results correspond with current research and theory, they confirm the Gluecks' own analyses.

Overall, then, major areas of the Gluecks' research-age and crime, longitudinal research/criminal careers, stability of crime and antisocial behavior, and social-control theory with a focus on family processeshave been shown to be either $(a)$ essentially correct or $(b)$ currently dominating the research agenda in criminology. Moreover, despite their methodological shortcomings, which were real and cannot be overlooked (see Laub and Sampson 1988, pp. 357-61), researchers have replicated the Gluecks' basic findings using new methods and procedures on their original data. Therefore, while the Gluecks' research has been disregarded by sociologists, as Snodgrass (1972, p. 245) predicted, it has not been discredited by subsequent research. Indeed, if the Gluecks' data and analysis were so poor and/or fudged as Sutherland claimed, it is virtually impossible that their findings would have been replicated time and time again by external investigators using other data and by our analyses of their original data. ${ }^{25}$

\section{CONCLUSIONS}

There is no doubt that Edwin Sutherland made substantial contributions to the field of criminology, especially in the areas of white-collar and professional crime and the development of the theory of differential association. Unlike other contemporaries (e.g., Clifford Shaw, Henry

\footnotetext{
${ }^{25}$ We also conducted a detailed validation of the Gluecks' data from the Unraveling study. Using the original handwritten interview schedules currently preserved at the Henry A. Murray Research Center of Radcliffe College in Cambridge, Mass., we successfully reconstructed the full longitudinal data set and found the data to be consistent with published reports as well as our own logical consistency checks. Moreover, we were able to trace and interview several members of the Gluecks' original research team for the Unraveling study, including Richard LaBrie, Mildred P. Cunningham, Sheila Murphrey, and Mary H. Moran. Taking all this information into account, we uncovered no evidence of anything other than meticulous data collection.
} 
McKay, Thorsten Sellin) Sutherland was also one of the first to offer a systematic theory that attempted to explain individual-level as well as macro-level differences in crime. $\mathrm{He}$ is thus appropriately revered as one of the most important criminologists to date, and his work continues to influence modern research (see Matsueda 1988).

Nevertheless, this state of affairs should not blind us to the brute force of Sutherland's critique of the Gluecks' work. Reflecting broader concerns about the shape and image of criminology in society, Sutherland's criticisms stemmed from his rejection of the multiple-factor approach, his adherence to a substantive version of sociological positivism, and his position as the dominant criminologist of the 20th century. When supplied with a false criterion of causality offered by his conversion to analytic induction, Sutherland felt free to dismiss the Gluecks' empirical contributions to criminological knowledge.

The power of Sutherland's critique is hard to overestimate. To this day sociological positivism is dominant and the Gluecks are often seen as relics of a distant past. Having been reified by the academic community, the Gluecks' fate has become so much a social fact that the bestselling criminology text in America (Siegel 1989), with over 1,000 references and 550 pages, cites the Gluecks but once. In true Sutherland tradition, the citation is to mesomorphy-by linking the Gluecks' work to "Lombrosians and other biological determinists" it is summarily rejected as "methodologically unsound" and "invalid" (Siegel 1989, p. 126). By contrast, our analysis has provided a revisionist assessment of the Gluecks' contributions to fundamental issues in criminological research that reaches the opposite conclusion.

Perhaps more important, however, our paper demonstrates the need to understand the processes by which knowledge is socially constructed. In particular, through a contemporary look at the Sutherland-Glueck debate we have provided new insights into the historical and intellectual context of criminological thought. Our findings support recent developments in intellectual historiography, which asserts that classic works in the history of ideas cannot be dealt with according to ordinary processes of causal explanation, but that their understanding presupposes a grasp of the authors' intentions and that this in turn requires the reconstruction of the conventions governing discussion of the issues of concern (see esp. Jones 1977; 1986, p. 618; Beirne 1987).

Moreover, we extended this approach to include an investigation of not only the historical context of the Sutherland-Glueck debate but the social positions and institutional settings they occupied within that context (see Camic 1987). We showed that the formation and substance of both Sutherland's and the Gluecks' positions were deeply affected by their respective methodological, disciplinary, and even institutional bi- 
ases. To Sutherland, the Gluecks' multiple-factor approach to crime represented a symbolic threat to the intellectual status of sociological criminology of which he was the leader, and hence his attack on the Gluecks' interdisciplinary thought served the larger interest of sociology in establishing proprietary rights to criminology. To the Gluecks, Sutherland represented abstract theorizing about crime from a unilateral (i.e., sociological) perspective. Moreover, this general theory was divorced from any social policy designed to prevent and control delinquency. Given the Gluecks' interest in using predictive techniques for pragmatic ends as well as their own lofty views of the importance of their research, they had no choice but to rebut Sutherland's critiques and launch a counterattack on all criminologists who disagreed with their position. The accepted fates of Sutherland and the Gluecks are thus interwoven and cannot be understood simply by reference to the truth or falsity of their research findings but instead must be placed within the social and institutional context of their debate.

In sum, our efforts support Jones's sobering yet penetrating conclusion: "For surely it is curious that, at the same time that modern sociologists struggle to expand their imaginations and thus to develop new ideas to account for the complexities of human behavior, there is nothing of which we are more ignorant than the nature of the process by which such ideas emerge, are received, grow, change, and are eventually surpassed" $(1977$, p. 311$)$. This is perhaps nowhere more true than in criminology, where "new" developments are constantly offered in what seems to be a collective amnesia about the past. We hope to have counteracted this tendency by specifying the social foundations of one of the major developments in criminological knowledge this century. ${ }^{26}$

\section{REFERENCES}

Abramson, Jill, and Barbara Franklin. 1986. Where They Are Now: The Story of the Women of Harvard Law 1974. New York: Doubleday.

Beirne, Piers. 1987. "Adolphe Quetelet and the Origins of Positivist Criminology." American Journal of Sociology 92:1140-60.

$\rightarrow$ Blumstein, Alfred, Jacqueline Cohen, and David P. Farrington. 1988. "Criminal Career Research: Its Value for Criminology." Criminology 26:1-35.

Blumstein, Alfred, Jacqueline Cohen, Jeffrey Roth, and Christy Visher, eds. 1986. Criminal Careers and "Career Criminals." Washington, D.C.: National Academy

Cabot, Richard C. 1926. Facts on the Heart. Philadelphia: Saunders.

Callwood, June. 1954. "Will Your Youngster Turn to Crime?" Maclean's Magazine, September 15.

${ }^{26}$ See Beirne (1987) for a sociological account of the 19th-century origins of positivist criminology. 
Camic, Charles. 1987. "Historical Reinterpretation of the Early Parsons." American Sociological Review 52:421-39.

Cohen, Albert K. 1970. "Multiple Factor Approaches." Pp. 123-26 in The Sociology of Crime and Delinquency, 2d ed. Edited by Marvin Wolfgang, Leonard Savitz, and Norman Johnston. New York: Wiley.

Cohen, Albert K., Alfred Lindesmith, and Karl Schuessler, eds. 1956. The Sutherland Papers. Bloomington: Indiana University Press.

Cohen, Lawrence E., and Richard Machalek. 1988. "A General Theory of Expropriative Crime: An Evolutionary Ecological Approach." American Journal of Sociology 94:465-501.

Current Biography Yearbook. 1957. "Glueck, Sheldon and Eleanor Touroff." 18:10-12. New York: H. W. Wilson.

Dressler, David. 1955. "You: The Newly Married-the Young Parent Can Prevent Delinquency." Everywoman's Magazine, September.

Faculty Committee Report. 1954. The Behavioral Sciences at Harvard. Eleanor T. and Sheldon Glueck Joint Papers. Harvard Law School Library, Cambridge, Mass.

Farrington, David P., and Donald West. 1981. "The Cambridge Study in Delinquent Development." Pp. 137-45 in Prospective Longitudinal Research, edited by S. Mednick and A. E. Baert. Oxford: Oxford University Press.

Frankfurter, Felix. 1934. Introduction to One Thousand Juvenile Delinquents, by Sheldon and Eleanor Glueck. Cambridge, Mass.: Harvard University Press.

Galliher, John F., and Cheryl Tyree. 1985. "Edwin Sutherland's Research on the Origins of Sexual Psychopath Laws: An Early Case Study of the Medicalization of Deviance." Social Problems 33:100-113.

Gaylord, Mark S., and John F. Galliher. 1988. The Criminology of Edwin Sutherland. New Brunswick, N.J.: Transaction.

Geis, Gilbert. 1966. "Review of Ventures in Criminology." Journal of Criminal Law, Criminology, and Police Science 57:187-88.

. 1970. "Review of Delinquents and Nondelinquents in Perspective." Crime and Delinquency 16:118-19.

Geis, Gilbert, and Colin Goff. 1983. Introduction to White Collar Crime: The Uncut Version, by Edwin H. Sutherland. New Haven, Conn.: Yale University Press.

- 1986. "Edwin H. Sutherland's White-Collar Crime in America: An Essay in Historical Criminology." Criminal Justice History 7:1-31.

Gibbons, Don. 1979. The Criminological Enterprise: Theories and Perspectives. Englewood Cliffs, N.J.: Prentice-Hall.

Gilboy, Elizabeth Waterman. 1936. "Interview with Eleanor Touroff Glueck." Barnard College Alumnae Monthly 26:11-12.

Glueck, Bernard. 1916. Studies in Forsenic Psychiatry. Boston: Little, Brown.

- 1918. "A Study of Six Hundred and Eight Admissions to Sing Sing Prison." Mental Hygiene 2:85-151.

Glueck, Eleanor. 1927. Community Use of Schools. Baltimore: Williams \& Wilkins. Press.

- 1966. "Identification of Potential Delinquents at 2-3 Years of Age." International Journal of Psychiatry 12:5-16.

Glueck, Sheldon. 1925. Mental Disorder and the Criminal Law. Boston: Little, Brown.

- 1934. Letter to H. H. Bingham, October 5. Sheldon Glueck Papers. Harvard Law School Library, Cambridge, Mass.

7.92. 1956. "Theory and Fact in Criminology." British Journal of Delinquency 7:92-109.

‥ 1960. "Ten Years of Unraveling Juvenile Delinquency: An Examination 
of Criticisms." Journal of Criminal Law, Criminology, and Police Science 51:283-308.

. 1962. Law and Psychiatry: Cold War or Entente Cordiale? Baltimore: Johns Hopkins University Press.

- 1964. "Remarks in Honor of William Healy, M.D." Mental Hygiene $48: 318-22$.

Glueck, Sheldon, and Eleanor Glueck. 1930. 500 Criminal Careers. New York: Knopf.

- 1934a. One Thousand Juvenile Delinquents. Cambridge, Mass.: Harvard University Press.

- 1934b. Five Hundred Delinquent Women. New York: Knopf.

1937 a. Later Criminal Careers. New York: The Commonwealth Fund.

1937b. "Analysis of Prof. Sutherland's Appraisal of Later Criminal Careers."

Sheldon Glueck Papers. Harvard Law School Library, Cambridge, Mass.

- 1937c. Letter to Edwin Sutherland, December 14. Eleanor T. and Sheldon

Glueck Joint Papers. Harvard Law School Library, Cambridge, Mass.

Fund.

. 1940. Juvenile Delinquents Grown Up. New York: The Commonwealth

1943. Criminal Careers in Retrospect. New York: The Commonwealth Fund.

- 1945. After-Conduct of Discharged Offenders. London: Macmillan.

Fund.

1950a. Unraveling Juvenile Delinquency. New York: The Commonwealth

- 1950b. "Review of Sheldon's Varieties of Delinquent Youth." Survey 86:215. 1951. "Note of Plans for Further 'Unraveling' Juvenile Delinquency." Jour-

nal of Criminal Law, Criminology, and Police Science 41:759-62.

- 1952. Delinquents in the Making. New York: Harper.

- 1959. Predicting Delinquency and Crime. Cambridge, Mass.: Harvard University Press.

Paul.

- 1964. Ventures in Criminology. Cambridge, Mass.: Harvard University Press. 1968. Delinquents and Nondelinquents in Perspective. Cambridge, Mass.: Harvard University Press.

- 1970. Toward a Typology of Juvenile Delinquency. New York: Grune \& Stratton.

. 1974. Of Delinquency and Crime. Springfield, Ill.: Thomas.

Goff, Colin. 1986. "Criminological Appraisals of Psychiatric Explanations of Crime: 1936-1950." International Journal of Law and Psychiatry 9:245-60.

Goring, Charles. (1913) 1972. The English Convict. Montclair, N.J.: Patterson Smith. $\rightarrow$ Gottfredson, Michael, and Travis Hirschi. 1986. "The True Value of Lambda Would Appear to Be Zero: An Essay on Career Criminals, Criminal Careers, Selective Incapacitation, Cohort Studies, and Related Topics." Criminology 24:213-34.

$\rightarrow-$. 1987. "The Methodological Adequacy of Longitudinal Research." Criminology 25:581-614.

26.37 1988. "Science, Public Policy, and the Career Paradigm." Criminology $26: 37-55$.

. 1990. A General Theory of Crime. Stanford, Calif.: Stanford University Press.

Hall, Livingston. 1937. "A Reply to Professor Sutherland's Review of Later Criminal Careers." Harvard Law Review 51:389-93.

Healy, William. 1915. The Individual Delinquent. Boston: Little, Brown.

Healy, William, and Augusta F. Bronner. 1926. Delinquents and Criminals: Their Making and Unmaking. New York: Macmillan. 
Hirschi, Travis. 1969. Causes of Delinquency. Berkeley: University of California Press.

- 1973. "Procedural Rules and the Study of Deviant Behavior." Social Problems 21:159-73.

- 1983. "Crime and the Family." Pp. 53-68 in Crime and Public Policy, edited by James Q. Wilson. San Francisco: Institute for Contemporary Studies.

Hirschi, Travis, and Michael Gottfredson. 1980. "Introduction: The Sutherland Tradition in Criminology." Pp. 7-19 in Understanding Crime, edited by Travis Hirschi and Michael Gottfredson. Beverly Hills, Calif.: Sage.

. 1983. "Age and the Explanation of Crime." American Journal of Sociology 89:552-84.

Hirschi, Travis, and Hanan C. Selvin. 1967. Delinquency Research: An Appraisal of Analytic Methods. New York: Free Press.

- 1970. "False Criteria of Causality." Pp. 127-40 in The Sociology of Crime and Delinquency, 2d ed. Edited by Marvin Wolfgang, Leonard Savitz, and Norman Johnston. New York: Wiley.

$\rightarrow$ Huesmann, L. Rowell, Leonard Eron, Monroe Lefkowitz, and Leopold Walder. 1984. "Stability of Aggression over Time and Generations." Developmental Psychology 20:1120-34.

Jones, Robert Alun. 1977. "On Understanding a Sociological Classic." American Journal of Sociology 83:279-319.

1986. "Durkheim, Frazer, and Smith: The Role of Analogies and Exemplars in the Development of Durkheim's Sociology of Religion." American Journal of Sociology 92:596-627.

Kornhauser, Ruth Rosner. 1978. Social Sources of Delinquency. Chicago: University of Chicago Press.

Laub, John H. 1983. Criminology in the Making: An Oral History. Boston: Northeastern University Press.

Laub, John H., and Robert J. Sampson. 1988. "Unraveling Families and Delinquency: A Reanalysis of the Gluecks' Data." Criminology 26:355-80.

Lazarsfeld, Paul F. 1955. "Interpretation of Statistical Relations as a Research Operation." Pp. 115-25 in The Language of Social Research, edited by Paul F. Lazarsfeld and Morris Rosenberg. New York: Free Press.

Lindesmith, Alfred. 1947. Opiate Addiction. Bloomington: Indiana University Press.

- 1988. Foreword to The Criminology of Edwin Sutherland, by Mark S. Gaylord and John F. Galliher. New Brunswick, N.J.: Transaction.

Loeber, Rolf. 1982. "The Stability of Antisocial Child Behavior: A Review." Child Development 53:1431-46.

$\rightarrow$ Loeber, Rolf, and Magda Stouthamer-Loeber. 1986. "Family Factors as Correlates and Predictors of Juvenile Conduct Problems and Delinquency." Pp. 29-150 in Crime and Justice: An Annual Review of Research, vol. 7. Edited by Michael Tonry and Norval Morris. Chicago: University of Chicago Press.

Mannheim, Hermann. 1965. Comparative Criminology. Boston: Houghton Mifflin. Smith.

Matsueda, Ross L. 1988. "The Current State of Differential Association Theory." Crime and Delinquency 34:277-306.

McCord, Joan. 1979. "Some Child-rearing Antecedents of Criminal Behavior in Adult Men." Journal of Personality and Social Psychology 37:1477-86.

Merton, Robert. 1971. Foreword to Masters of Sociological Thought: Ideas in Historical and Social Context, by Lewis Coser. New York: Harcourt Brace Jovanovich.

Michael, Jerome, and Mortimer J. Adler. 1933. Crime, Law, and Social Science. New York: Harcourt Brace. 
Morgan, Thomas B. 1960. "Now We Can Spot Delinquents Early." Think Magazine, March, pp. 2-6.

$\rightarrow$ Olweus, Daniel. 1979. "Stability of Aggressive Reaction Patterns in Males: A Review." Psychological Bulletin 86:852-75.

Patterson, Gerald. 1982. Coercive Family Process. Eugene, Oreg.: Castalia.

Potts, David P. 1965. "Social Ethics at Harvard, 1881-1931: A Study in Academic Activism." Pp. 91-128 in Social Sciences at Harvard, 1860-1920. Cambridge, Mass.: Harvard University Press.

Reckless, Walter. 1941. "Review of the Gluecks' Juvenile Delinquents Grown Up." American Journal of Sociology 46:736-38.

Reiss, Albert J., Jr. 1951. "Unraveling Juvenile Delinquency. II. An Appraisal of the Research Methods." American Journal of Sociology 57:115-20.

Robins, Lee. 1966. Deviant Children Grown Up. Baltimore: Williams \& Wilkins.

Rowe, David, and D. Wayne Osgood. 1984. "Heredity and Sociological Theories of Delinquency: A Reconsideration." American Sociological Review 49:526-40.

Schneider, Alexander J. N., Cyrus W. LaGrone, Jr., Eleanor T. Glueck, and Sheldon Glueck. 1944. "Prediction of Behavior of Civilian Delinquents in the Armed Forces." Mental Hygiene 28:456-75.

Schuessler, Karl, ed. 1973. Edwin H. Sutherland on Analyzing Crime. Chicago: University of Chicago Press.

Sellin, Thorsten. 1938. Culture Conflict and Crime. New York: Social Science Research Council.

Sheldon, William H. 1949. Varieties of Delinquent Youth: An Introduction to Constitutional Psychiatry. New York: Harper.

Siegel, Larry, 1989. Criminology, 3d ed. Minneapolis: West.

Snodgrass, Jon. 1972. The American Criminological Tradition: Portraits of the Men and Ideology in a Discipline. Ann Arbor, Mich.: University Microfilms International.

- 1973. "The Criminologist and His Criminal: Edwin H. Sutherland and Broadway Jones." Issues in Criminology 8:1-17.

Sutherland, Edwin H. 1924. Criminology. Philadelphia: Lippincott.

. 1929. Letter to Sheldon Glueck, September 27. Sheldon Glueck Papers. Harvard Law School Library, Cambridge, Mass.

1934a. Principles of Criminology, 2d rev. ed. Philadephia: Lippincott.

1934b. "Review of the Gluecks' One Thousand Juvenile Delinquents." Journal of Criminal Law, Criminology, and Police Science 25:144-46.

. 1936. Letter to Sheldon Glueck, May 4. Sheldon Glueck Papers. Harvard Law School Library, Cambridge, Mass.

. 1937a. The Professional Thief. Chicago: University of Chicago Press.

1937b. "Review of Gluecks' Later Criminal Careers." Harvard Law Review

$51: 184-86$.

. 1937c. "The Gluecks' Later Criminal Careers: An Appraisal by Edwin Sutherland." Eleanor T. and Sheldon Glueck Joint Papers. Harvard Law School Library, Cambridge, Mass.

- $1937 d$. Letter to Sheldon Glueck, December 4. Sheldon Glueck Papers. Harvard Law School Library, Cambridge, Mass.

- 1938. Letter to Eleanor Glueck, January 11. Sheldon Glueck Papers. Harvard Law School Library, Cambridge, Mass.

—. 1944a. "Review of Gluecks' Criminal Careers in Retrospect." American Bar Association Journal 30:142.

1944b. Letter to Sheldon Glueck, February 11. Eleanor T. and Sheldon

Glueck Joint Papers. Harvard Law School Library, Cambridge, Mass.

- 1947. Principles of Criminology, 4th ed. Philadelphia: Lippincott. 


\section{American Journal of Sociology}

1949. White Collar Crime. New York: Dryden.

1951. "Critique of Sheldon's Varieties of Delinquent Youth." American Sociological Review 16:10-13.

1983. White Collar Crime: The Uncut Version. New Haven, Conn.: Yale University Press.

Sutherland, Edwin H., and Donald R. Cressey. 1955. Principles of Criminology, 5th ed. Chicago: Lippincott.

1978. Principles of Criminology, 10th ed. Philadelphia: Lippincott.

Taft, Donald. 1937. "Review of Gluecks' Later Criminal Careers." American Sociological Review 2:940-41.

Turner, Ralph. 1953. "The Quest for Universals in Sociological Research." American Sociological Review 24:605-11.

Udry, J. Richard. 1988. "Biological Predispositions and Social Control in Adolescent Sexual Behavior." American Sociological Review 53:709-22.

Vaillant, George E. 1980. "Glueck, Eleanor Touroff." Pp. 278-80 in Notable American Women: The Modern Period, edited by Barbara Sickerman and Carol Hurd Greer. Cambridge, Mass.: Harvard University Press. 